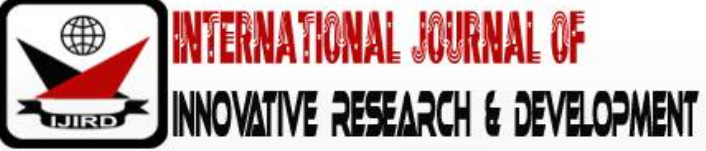

ISSN 2278 - 0211 (Online)

\section{Level of Youth Participation in Agro-Processing Enterprises in the Western Agricultural Zone of Nasarawa State, Nigeria}

\author{
E. A. Ubana \\ Lecturer, Department of Agricultural Extension Technology, Federal College of Forestry, Jos, Nigeria \\ A.S Bako \\ Lecturer, Department of Agriculture, Nasarawa State University Keffi, Shabu-Lafia Campus, Nigeria
}

\begin{abstract}
:
The study examined the level of youth participation in agro-processing enterprises in the Western Agricultural Zone of Nasarawa State, Nigeria. A multi-stage sampling procedure was used to draw 120 youths from 12 villages who served as respondents. Questionnaire was used to elicit information from the respondents. Data were analyzed with descriptive statistics such as percentage, mean scores and ranking and likert rating scale was used to measure level of performance. Results show that majority (60.8\%) of the respondents were male; within the age bracket of 21 - 40 years (84.2\%) while the mean age of the respondents was 30 years. Most respondents (81.8\%) had one level of formal education or the other. The average years of experience in agro-processing was1 1 years, while mean annual income was N402, 250.00. The predominant agro-processing enterprises undertaken by the respondents were groundnut oil processing $86.3 \%$, maize flour processing $77.5 \%$ and cassava processing $67.5 \%$. The level of youth participation in agro-processing show that participation in groundnut oil processing, maize flour processing and garri and cassav a flour (alubo) processing were rated very high. Groundnut oil processing had a mean score of 2.86, maize flour processing had a mean score of 2.76 and garri and cassava flour (alubo) processing had a mean score of 2.63.The major constraints faced by the respondents were inadequate capital to expand their businesses (86.7\%), poor access to credit facilities (70.0\%) and high cost of raw materials and processing facilities and equipment (65.8\%). It was recommended that credit facilities should be made more flexible to young people who want to go into agricultural processing enterprises. This will promote entrepreneurship and job creation among the youth.
\end{abstract}

Keywords: Youth participation, agro-processing, processing-based enterprises

\section{Introduction}

Considering the challenges of increase in human population, low yield due to pest and disease attack on cultivated crops and poor level of mechanized agricultural activities, then agricultural product processing and storage in other to meet these necessities becomes of crucial importance. If we process and store our food crops we make it more durable, attractive and add value to it, this can go a long way in mitigating global food insecurity (Adiaha, 2017).

A very large part of agricultural production undergoes some degree of transformation between harvesting and final use. Agricultural processing is any activity that maintains, raises the quality or changes the form or characteristics of an agricultural product. Between harvest and consumption, a produce goes through various unit operations. These unit operations bring about transformation in physical structure and sometimes chemical composition. Basic unit operations include cleaning, separation, size reduction, drying, heat exchange, mixing, and packaging (Adiaha, 2017).

Typically, agricultural processing increases in importance relative to agriculture and occupies a dominant position in manufacturing as developing countries step up their growth. Basic processing trends are in both non-food and food sectors as a whole. This study focuses on the food sector.

According to Alonge (2016) agricultural processing enterprises include:

Groundnut processing: The products obtained from groundnut are groundnut oil and cake.

Rice processing: The unit operations involved in processing rice is threshing, cleaning, grading, soaking, steaming, parboiling, drying, milling, destoning, and size grading and bagging.

Cassava processing: The end products of cassava include; garri (cassava flakes), fufu, flour, starch, animal feeds, chips and pellets Oil palm processing: The end products of its processing are palm oil, palm kernel oil, cake, shell and the briquettes.

Yam processing: This can be processed into flour and flakes.

Soybean processing: Soybean can be processed into products as soymilk, soya yoghurt, soya oil and cake (Awara).

Processing of fruits and vegetables: Non-leafy vegetables such as okra, tomatoes, and pepper are sliced and dried to the requisite moisture content for later use while fruits such as oranges, mangoes; pineapples are processed in factories into fruit juice concentrates and jams. 
Meat processing: Livestock produce include cattle, goat, sheep and pig. Cattles are produced for the meat and dairy. The skins of the cattle are further processed into hide and skin for the leather and shoe industries. Meats are locally prepared at abattoirs.

Poultry processing: Poultry meat is processed by slaughtering, de-feathering, cutting before storage. Fish processing: Fish can be processed by drying, smoking or cold storage.

Youths have been differently defined by various authors worldwide. Okogun (2004) declared that, "youthful period" is the time when a man's power and attributes are developed to highest potential. It is a period when man's intellect is at its highest peak. According to the Nigeria National Youth Development Policy (NYDP, 2009), a youth is described as any person between the age of 18 and 35 years. This stratum of the Nigeria population makes up 80 percent of the total population and constitutes about 76 percent of the agricultural labour force.

Participation as a concept is however a contested subject. Participation is a rich concept that means different things to different people in different settings. With regards to rural development; participation include people's involvement in decision making process, implementing programmes, their sharing in the benefits of development programmes and their involvement in efforts to evaluate such program (Afande et al., 2015).

The participation of youths in agro-processing enterprises has been described as very important structure for agrarian reform as well as agribusiness which will go a long way towards promoting the interest of the agricultural sector of the economy and help the youths live above poverty level (Alonge, 2016).

According to Afande et al., (2015), Youths are the successor farming and processing generation and therefore the future of food security in Nigeria. The ageing smallholder processors are less likely to adopt the new technologies needed to sustainably increase agricultural processing hence the need to encourage youth participation in agricultural processing enterprises.

\subsection{Purpose of the Study}

A lot of agro-processing enterprises abound in Nasarawa state that can provide gainful employment opportunities for the teaming youths and yet many of the rural youths are still unemployed. There is also general youth apathy towards agro-processing enterprises. The need to scientifically assess the reasons behind this youth apathy to agro-processing in the state is the knowledge gap this study seeks to fill. The purpose of this study is to determine the level of youth participation in agro-processing enterprises in the Western Agricultural Zone of Nasarawa State, Nigeria. The specific objectives are to:

- Describe the socio-economic characteristics of youths;

- Determine the most common types of agro-processing enterprises undertaken by youth;

- Determine the level of youth participation in agro-processing enterprises;

- Identify the constraints to youth's participation in agro-processing enterprises.

\section{Methodology}

\subsection{Study Area}

The study was conducted in the Western Agricultural Zone of Nasarawa State, Nigeria. The Western Agricultural Zone comprises of four (4) Local Government Areas (LGAs) namely; Keffi, Karu, Nasarawa and Toto with its zonal headquarters in Keffi. The zone lies within the guinea savannah climate with annual rainfall ranging between 1,000$1,500 \mathrm{~mm}$. The zone is located between latitude $85^{\prime}$ and $853^{\prime} \mathrm{N}$ of the equator and longitude $7,50^{\prime} \mathrm{E}$ and $751^{\prime} \mathrm{E}$ of the Greenwich Meridian. The zone has the mean annual mean temperature ranging from $23{ }^{\circ} \mathrm{C}-37{ }^{\circ} \mathrm{C}$ (Nasarawa State Agricultural Development Programme [NADP], 2017).

\subsection{Sampling Technique and Sample Size}

The target population of the study comprised of all rural youth including young men and women. A multi-stage sampling procedure was used for the selection of the respondents.

- Stage 1: Three (3) LGAs namely Keffi, Karu and Nasarawa were purposively selected out of the four (4) LGAs that make up the Western Agricultural Zone of the state.

- Stage 2: Four villages were selected from each of the 3 selected LGAs using a simple random sampling technique. This gave twelve (12) villages that were used for the study.

- Stage 3: Ten (10) youths were selected from each of the 12 selected villages using a simple random sampling technique. This gave a total of 120 youths as respondents for the study.

\subsection{Data Collection}

Method of data collection was through the use of a structured questionnaire.

\subsection{Data Analysis}

Data were analyzed using simple descriptive statistics such as frequency counts, mean scores and percentages. The simple descriptive statistics such as frequency counts, mean scores and percentages was used to analyze objective i, ii and iv while to achieve objective iii a 4-point Likert scale was used to measure degree of performance. 


\subsection{Likert Rating Scale Technique}

To identify the constraints to the effective performance of Farmers' Multipurpose Cooperative Societies, 4-point likert rating scale was employed. The 4-point likert rating scale was graded as Very High $(\mathrm{VH})=4$, High $(\mathrm{H})=3$, Low $(\mathrm{L})=$ 2 , Very Low (VL) 1 . The mean score of respondents based on the 4-point Likert rating scale was computed; $4+3+2+1=$ $10 / 4=2.50$ cut off point Using the interval scale of 0.05 , the upper limit cut-off point is $2.50+0.05=2.55$; the lower limit is $2.50-0.05=2.45$. On the basis of the limit, mean scores below 2.45, (i.e. MS <2.45) were ranked "Not serious; those between 2.45 and 2.54 were considered 'Serious' (i.e. $2.45>\mathrm{MS}<2.54$ ) while mean scores that are greater than or equal to 2.55 (i.e. $\mathrm{MS} \geq 2.55$ ) were considered 'Very serious'.

\section{Results and Discussion}

\subsection{Socio-Economic Characteristics of the Respondents}

Table 1 shows the distribution of the respondents according to their socioeconomic characteristics. Majority $(84.2 \%)$ of respondents were within the age range of 21-40 years. The mean age of the respondents was 38 years. This implies that the respondents were very young and energetic people who can undertake agricultural tasks. Also, majority $(60.8 \%)$ of the respondents were males while $39.2 \%$ were females. This implies that males participated in agroprocessing enterprises more than females in the study area. This may be due to the drudgery associated with agroprocessing enterprises. Table 1 also shows that $31.6 \%, 30.0 \%$ and $20.2 \%$ of the respondents had tertiary, secondary and primary education respectively while only $18.2 \%$ of them had no formal education. This implies that majority (81.8\%) of the respondents had some form of formal education. Formal education can influence decision making concerning agroprocessing enterprises. This finding is in agreement with that of Amaza et al., (2009) who reported that a greater percentage of the youth in Southern Borno State, Nigeria who participates in agriculture (93.64\%) had some form of formal educations. They opined that formal education would help youth to use the production and technical information efficiently and to also learn new things within a short period of time.

On their contact with Extension, the results in Table 1 show that majority (75.0\%) of the respondents did not have access to extension service while only $25.0 \%$ had contact with extension agents. This implies that extension contact which is supposed to be one of the main sources of agricultural information/ technologies was insufficient in the study area. This may negatively affect their level of participation in agro-processing enterprises. This finding is similar to that of Bello et al., (2014) who reported that only 35.0\% of the youth involved in rice production in Lafia LGA of Nasarawa State had access to extension services. Results in Table 1 also show that majority (75.0\%) of the respondents did not have access to credit while only $25.0 \%$ were able to obtain loan. This shows that the respondents were incapacitated by inadequate finance to invest in agro-processing enterprises. This would result in low scale of agro-processing, low output and also low income and therefore perpetual poverty.

Majority (60.8\%) of the respondents had 1-10 years of experience in agro-processing enterprises. The mean years of agro-processing experience of the respondents was 11 years. This implies that most respondents had some level of experience in agro-processing enterprises in the study area. Experience is very important because it enhances managerial capability of an entrepreneur. Longer years of experience lead to higher management skills. According to Salau et al., (2013), experience is very important because it enhances managerial capability of an entrepreneur. The longer the years of agro-processing experience the higher the processing management skills.

Majority (65.8\%) of respondents had annual income level of between N1,000 - N400,000:00 followed by 18.4\% who earned between N401,000:00-N800,000:00 annually while 15.8\% of respondents earned above N800,000:00. The mean annual income of the respondents was N402, 250:00.This implies that youths in the study area earned low income. Agbamu (2006) noted that it is not always easy to determine the level of income of Nigerian farmers because some of them do not keep records while others are skeptical about disclosing their income.

\begin{tabular}{|c|c|c|}
\hline Variable & Frequency & Percentage (\%) \\
\hline Age (years) & 7 & \\
$1-20$ & 113 & 15.8 \\
$21-40$ & & 84.2 \\
\hline Sex & 73 & 60.8 \\
Male & 47 & 39.2 \\
\hline Female & & \\
\hline Education & 17 & 18.2 \\
Non-formal education & 39 & 20.2 \\
Primaryeducation & 38 & 30.0 \\
Secondary school education & & 31.6 \\
Tertiary education & 29 & 25.0 \\
\hline Extension Contact & 91 & 75.0 \\
Had access to extension contact & 30 & 25.0 \\
Had no extension contact & 90 & 75.0 \\
Access to Credit & & \\
Yes & & \\
No & & \\
\hline
\end{tabular}




\begin{tabular}{|c|c|c|}
\hline Variable & Frequency & Percentage (\%) \\
\hline Enterprise experience (in years) & & \\
\hline $1-10$ & 73 & 60.8 \\
$11-20$ & 42 & 35.0 \\
Above 20 & 5 & 4.2 \\
Farm Size (in ha) & 114 & 95.0 \\
$1-10$ & 5 & 4.2 \\
$11-20$ & 1 & 0.8 \\
Above 20 & & \\
\hline Annual income (in naira) & 99 & 82.5 \\
1,000-400,000 & 13 & 10.8 \\
Ab1,000-800,000 & 8 & 6.7 \\
Above 800,000 & 120 & 100 \\
\hline
\end{tabular}

Table 1: Socio-Economic Characteristics of Respondents ( $\mathrm{N}=120)$

Source: Field Survey 2018

$\mathrm{N}=$ Sample Size

\subsection{Types of Agricultural Processing Enterprises by the Respondents}

The results in Table 2 show the distribution of respondents based on types of agro-processing enterprises undertaken. Majority (86.3\%) were into groundnut oil processing, maize flour processing $77.5 \%$ and cassava processing (Garri and cassava flour) 67.5\%. Others were beef 57.5\%, sorghum drink (kunu) 55.0\%, beef Barbeque (suya) and fish smoking $45.0 \%$ and rosette drink (Zobo) $25.5 \%$. This implies that there were a number of agro-processing enterprises youths can involved in as a source of livelihood in the area.

\begin{tabular}{|c|c|c|c|}
\hline Variable & Frequency & Percentage (\%) & Rank \\
\hline Groundnut oil processing & 104 & 86.3 & 1 \\
Maize flour processing & 93 & 77.5 & 2 \\
Garri Cassava flour (Alubo) processing & 81 & 67.5 & 3 \\
Beef processing & 69 & 57.5 & 5 \\
Sorghum drink (Kunu) processing & 66 & 55.0 & 6 \\
Beef barbeque (Suya) & 54 & 45.0 & 7 \\
Fish smoking & 54 & 45.0 & 7 \\
Rosette drink (Zobo) & 30 & 25.5 & 8 \\
\hline
\end{tabular}

Table 2: Specific Agricultural Processing Enterprises by the Respondents

Source: Field Survey 2018

Multiple Responses

\subsection{Level of Youth Participation in Various Agro-Processing Enterprises}

Results in Table 3 show that groundnut oil processing, maize flour processing and garri and cassava flour (alubo) processing were rated very high. Groundnut oil processing had a mean score of 2.86, maize flour processing had a mean score of 2.76 and garri and cassava flour (alubo) processing had a mean score of 2.63. Beef processing and sorghum drink (kunu) processing were rated high. Beef processing had a mean score of 2.50 while sorghum drink (kunu) processing had a mean score of 2.48. The very high participation of youths in groundnut oil processing, maize flour processing and garri and cassava flour (alubo) processing enterprises show that participation was as a means of self-employment. This has strong impact in the economy as it will help reduce the level of youth unemployment. This agrees with the finding of Gerei et al., (2016) that youth in Obi Local Government Area, Nasarawa State, Nigeria participate in agricultural ventures to create job for themselves in order to reduce restiveness and as a means of reducing poverty among them.

\begin{tabular}{|c|c|}
\hline Performance Indicator & Mean score \\
\hline Groundnut oil processing & $2.86^{* *}$ \\
Maize flour processing & $2.76^{* *}$ \\
Garri Cassava flour (Alubo) processing & $2.63^{* *}$ \\
Beef processing & $2.50^{*}$ \\
Sorghum drink (Kunu) processing & $2.48^{*}$ \\
Beef barbeque (Suya) & 2.37 \\
Fish smoking & 1.80 \\
Rosette drink (Zobo) & 1.61 \\
\hline
\end{tabular}

Table 3: Level of Youth Participation in Various Agro-Processing Enterprises Field Survey (2018)

Multiple Responses Observed.

VH=Very High (4), H=High (3), L=Low (2), VL=Very Low (1) $* *=$ Very High,$*=$ High 


\subsection{Constraints to Youth Participation in Agro-Processing Enterprises}

Results in Table 4 show the constraints facing youths' participation in agro-processing enterprises in the study area. These include inadequate capital to expand their businesses (86.7\%), poor access to credit to purchase the agroprocessing equipments $(70.0 \%)$, high cost of raw materials and processing facilities and agro-processing equipments (65.8\%), inadequate storage facilities (58.3\%), lack of extension services on latest technology on agro-processing (55.0\%), inadequate technical skills (52.2\%) and unfavourable government policies (50.0\%). This implies that youth were faced with several constraints that reduce their participation in agro-processing enterprises. Thomas, (2014) in his study "Determinants of Participation in Youth-in-Agriculture Programme" in Ondo State, Nigeria also identified the major constraints facing agricultural enterprises to include inadequate capital; inadequate skilled personnel, poor infrastructure such as transport, processing, storage and marketing facilities among others.

\begin{tabular}{|c|c|c|c|}
\hline Constraint & Frequency & Percentage (\%) & Rank \\
\hline Inadequate capital to expand their businesses & 104 & 86.7 & $1^{\text {st }}$ \\
Poor access to credit facilities & 84 & 70.0 & $2^{\text {nd }}$ \\
High cost of raw materials and processing facilities and equipments & & & \\
Inadequate storage facilities & 79 & 65.8 & $3^{\text {rd }}$ \\
Lack of extension services on latest technology on processing & 70 & 58.3 & $4^{\text {th }}$ \\
Inadequate technical skills & 66 & 55.0 & $5^{\text {th }}$ \\
Unfavourable government policies & 63 & 52.5 & $6^{\text {th }}$ \\
& 60 & 50.0 & $7^{\text {th }}$ \\
\hline
\end{tabular}

Table 4: Constraints to Youth Participation in Agricultural Enterprises

Source: Field Survey 2018

Multiple Responses

\section{Conclusion and Recommendations}

\subsection{Conclusion}

The study has revealed that youth in the Western Agricultural Zone of Nasarawa State were involved in three major agro-processing enterprises namely groundnut oil processing, maize flour processing andgarri / cassava flour (Alubo) processing. The level of youth participation in agro-processing show that participation in groundnut oil processing, maize flour processing and garri and cassava flour (alubo) processing were rated very high.However, youth faced some major constraints such as inadequate capital to expand their businesses, poor access to credit to purchase the agro-processing equipments and high cost of raw materials and processing facilities and agro-processing equipments among others.

\subsection{Recommendation}

It was recommended that governments at all levels should provide more incentives such as credit facilities, subsidized agro-processing machines and provide capacity training for youth in agro-processing enterprises to enhance higher productivity and profit.

\section{Reference}

i. Adebayo, A. A. (2009).Constraints to Participation in Income Generating Enterprises among Youths in Birnin Gwari LGA, Kaduna State, Nigeria. Journal of Agricultural Extension Vol. 13 (1).

ii. Adiaha, M. S. (2017) Complete Guide to Agricultural Product Processing and Storage. World Scientific News 81(1) (2017) 1-52

iii. Afande F. O., Maina W. N. and Maina, M. P. (2015).Youth engagement in agriculture in Kenya: challenges and prospects, Journal of Culture, Society and development7,pp. 419.

iv. Alonge A.F. (2016). Food Processing, Preservation and Storage for Economic Development in Nigeria. Proceedings of the 11th International Conference and 32nd Annual General Meeting of the Nigerian Institution of Agricultural Engineers (NIAE Ilorin 2011), October 17 - 20, 2011, Ilorin, Nigeria. ISBN: $\quad$ 978-036-5788.https:/ / www.researchgate.net/ publication/ 290821225.

v. Amaze, P., Tahirou, A., PAatrick, K., and Amare, T. (2009). Challenges in household food security and poverty status in PROSAB area of Southern Borno State, Nigeria. Promoting Sustainable Agriculture in Borno State (PROSAB). International Institute of Tropical Agriculture, Ibadan, Nigeria.1-40.

vi. Bello M., Galadima, O. E. 1 , Anzaku, T. K. A. and Allu, E (2014), Analysis of Youth Involvement in Rice Production in Lafia Local Government Area in Nasarawa State of Central Nigeria. Research Journal of Agriculture and Environmental Management. Vol. 3(6), pp. 281-289 http:/ / www.apexjournal.org. ISSN 2315 - 8719 @ 2014 Apex Journal International Full-Length Research.

vii. Girei A. A. , Saingbe N. D. , Ohen S. B. , Gimba E.A. (2016), Youth Involvement in Agricultural Production in Obi Local Government Area, Nasarawa State, Nigeria. International Journal of Environment, Agriculture and Biotechnology.(IJEAB),Vol-1,Issue-4.http:/ / dx.doi.org/ 10.22161/ ijeab/ 1.4.54ISSN: 2456-1878 www.jjeab.comPage 1016. 
viii. National Youth Development Policy, (2009). Document of the Federal Republic of $\quad$ Nigeria.

ix. Nasarawa State Agricultural Development Programme (NADP), zonal office bulletin Keffi, November (2017).

x. Okogun, S. A. (2004). Youth's participation in farming activities in Edo state. An unpublished B. Sc project in the Department of Agricultural Extension and Rural Development University of Ibadan, Ibadan Nigeria. 2004; Pp. 35. 17.

xi. Olanrewaju, B. (2010). "The map of history: Agriculture Our Future." Nigeria.

xii. Salau, E.S, Saingbe, N. D. and Garba, M. N. (2013).Agricultural Information Needs of Small Holder Farmersin Central Agricultural Zone of Nasarawa State. Journal of Agricultural Extension Vol.17 (2). Retrieved on 27/ 7/ 2018 from http:/ / dx.doi.org/ 10.4314/ jae.v17i2.15.

xiii. Thomas, K.A. (2014). Determinants of Participation in Youth-in-Agriculture Programme in Ondo State, Nigeria. International Journal of Environment, Agriculture and Biotechnology (IJEAB): Vol 1, No 4.

xiv. World Bank, (2008). World Development Report 2008: Applying the WDR World-Wide. 